\title{
EU Citizens, Foreign Family Members and European Union Law
}

\author{
Elspeth Guild \\ Professor Jean Monnet Professor ad personam, Radboud University \\ Nijmegen, the Netherlands and Queen Mary University of London, UK
}

\begin{abstract}
While international human rights law enshrines family life as a cornerstone of society, when it intersects with migration, issues and problems arise in countries where migration is high on the political agenda. This is true in a number of EU states. Both EU law and European human rights commitments, however, require states to provide for family reunification subject to a margin of discretion to the state. While family reunification for refugees and beneficiaries of international protection has been at the top of some political agendas in Europe, this article looks at family reunification (generally known as family reunion) for another group—nationals of the Member States. In particular it poses two questions: do EU Member States accept their own nationals to come back to their home state with third country national family members they have acquired while abroad? Secondly, to what extent do EU Member States discriminate against their own nationals in comparison with the generous EU rules of family reunion for nationals of other Member States who have exercised a free movement right in their country. This article is based on reports by experts from all EU Member States in light of the 2014 judgment in $O \& B\left(\mathrm{C}-45^{6 / 12}\right)$ by the Court of Justice of the European Union.
\end{abstract}

\section{Keywords}

EU citizenship - family members - family reunification - reverse discrimination 
The enjoyment of family life is a human right which has multiple sources in the international, regional and constitutional spheres. ${ }^{2}$ In Europe, the right to respect for family life in the European Convention of Human Rights has long been a beacon of hope for families struggling to enjoy family life but separated because of their nationalities. ${ }^{3}$ But it is also often a disappointment for families as the jurisprudence of the European Court of Human Rights often recognises a substantial margin of appreciation for states in determining the degree of respect which the family life of people of different nationalities should be facilitated on their territory. ${ }^{4}$ EU law has engaged with family reunion of EU citizens with their third country national family member since 1964 when it adopted a regulation about the rights of workers. ${ }^{5}$ These rules are much more constraining than the human right to respect for family life as they create a right to family reunion for EU citizens who move and reside in another Member State, against which states must justify any interference if they wish to prevent family reunion. The EU only developed rules on family reunification for third country nationals resident there in 2003 and those rules are much less generous than the ones applicable to EU citizens. ${ }^{6}$

This article examines the right of EU citizens to enjoy family life with their third country nationals family members (third country nationals are nationals of any state which is not an EU or European Economic Area country). The purpose of this examination is to understand whether and in what ways the EU rules applicable to EU citizens and their family members create friction in the Member States. For these purposes the key EU rules come from Articles 2

1 This article is based on research performed as part of the Centre of Migration Law's Jean Monnet Centre of Excellence work programme 2015-2018 funded by the European Commission under contract number 565027-EPP-1-2015-1-NL-EPPJMO-CoE.

2 https://www.coe.int/en/web/commissioner/-/ending-restrictions-on-family-reunification -good-for-refugees-good-for-host-societies, visited 17 April 2019.

3 S. Peers (2017) 'Immigration, asylum and human rights in the European Union', in: S. Douglas-Scott \& N. Hatzis (Eds), Research Handbook on EU Law and Human Rights (Cheltenham: Edward Elgar Publishing), p. 439-450.

4 M.-B. Dembour (2006)Who believes in human rights?: Reflections on the European Convention (Cambridge: Cambridge University Press).

5 E. Guild (2002) 'Immigration law in the European Community', Refugee Survey Quarterly, p. $379-380$.

6 K. Groenendijk (2006) 'Family reunification as a right under community law', European Journal of Migration and Law 8(2), p. 215-230. 
and 3 Directive 2004/38. ${ }^{7}$ An EU citizen and his or her family members of any nationality have the right to move and reside freely in the EU. For the first three months they are not required to provide any reasons for their stay in a host Member State. After three months they must fulfil the conditions of workers, self-employed, students, pensioners, economically self-sufficient or otherwise enjoy an entitlement to reside. ${ }^{8}$ Family members are entitled to accompany or join their EU national principal in the host Member State and are entitled to exercise economic activities in line with their principal. The reason for this, according to the Directive's preamble, is to permit the EU citizen to exercise his or her free movement right under objective conditions of freedom and dignity, which require that the same right be granted to their family members, irrespective of nationality (recital 5).

The class of family members with an entitlement to accompany or join their principal in a host Member State consists of: spouses (including same sex spouses); the partner with whom the Union citizen has contracted a registered partnership on the basis of the legislation of a Member State; direct descendants who are under the age of 21 or are dependants and those of the spouse or partner; dependent direct relatives in the ascending line and those of the spouse or partner (Article 2 Directive 2004/38). A wider group of family members as well as durable partners are entitled to facilitation under Article 3 of the Directive. For family members to have a right to accompany or join the EU citizen principal, the conditions are very limited. If the family members are aboard, Member States are required to facilitate the issue of visas which are free. There are no fees payable for family reunion applications. If the EU citizen is a worker or self-employed (as defined in EU law) ${ }^{9}$ no conditions regarding income or housing are permitted. There is no requirement for health insurance for the family other than that which applies to all citizens of the state. The family is entitled to social benefits on the same basis as citizens of

7 Directive 2004/38/EC of the European Parliament and of the Council of 29 April 2004 on the right of citizens of the Union and their family members to move and reside freely within the territory of the Member States amending Regulation (EEC) No 1612/68 and repealing Directives 64/221/EEC, 68/360/EEC, 72/194/EEC, 73/148/EEC, 75/34/EEC, 75/35/EEC, 90/364/EEC, 90/365/EEC and 93/96/EEC (Text with EEA relevance).

8 H. Verschueren (2015) 'Preventing "benefit tourism" in the EU: A narrow or broad interpretation of the possibilities offered by the ECJ in Dano?', Common Market Law Review $5^{2(2),}$ p. 363-39o; H. Verschueren (2015) 'Free movement of EU citizens: including for the poor?', Maastricht Journal of European and Comparative Law 22(1), p. 10-34; K. Lenaerts (2015) 'EU citizenship and the European Court of Justice's "stone-by-stone" approach', International Comparative Jurisprudence $1(1)$, p. 1-10.

9 E. Guild, S. Peers \& J. Tomkin (2014) The EU citizenship directive: a commentary (Oxford: Oxford University Press). 
the state. The family members do not have to live together and family members who entered the state as dependants are entitled to seek employment and become financially independent. ${ }^{10}$ For students, pensioners and the selfsufficient, the rules are slightly stricter with a (low) financial threshold and comprehensive sickness insurance requirement. All EU citizens and their family members are entitled to permanent residence after five years fulfilling the conditions. Once they have this status they no longer need to fulfil even these quite simple conditions. They can only be expelled on grounds of public policy or public security, as defined by EU law. ${ }^{11}$ According to the jurisprudence of the Court of Justice of the European Union (CJEU), EU citizens who have genuinely exercised a free movement right in another Member State are entitled to return to this home Member State and bring with them their family members acquired while away under the same conditions as those under which they were entitled to join the principal in the host Member State. ${ }^{12}$

This last group is the source of friction between some Member States and EU which I will consider here. A number of Member States have introduced much stricter rules for family reunion of their own citizens when in their own state. These restrictions include: high visa and application fees; substantial income thresholds to qualify; mandatory sickness insurance; no access to social benefits for substantial periods; language tests; integration tests; more restricted categories of family members eligible for admission. However, Member States cannot prevent their citizens from moving to another Member State, exercising a free movement right there, being joined by their third country national family members in accordance with EU (more generous) rules and coming back to their home state. The CJEU first held that EU citizens had a right to return home with their family members on the same conditions as when they took up residence in a host state in $1992 .{ }^{13}$ Thus EU citizens could avoid the more difficult conditions of their national law on family reunion by using their EU rights. Some Member States see this as an abuse of EU rights, though this has not been accepted by the CJEU. Since 1992, a number of cases have come before the CJEU seeking clarification of the right of these EU citizens to return home and still enjoy their EU family reunion rights. This is perhaps not surprising as the farther national law moves from EU law on family reunion the greater the discrimination regarding family reunion between citizens of a state who have not exercised a free movement right and those who have becomes.

\footnotetext{
$10 \quad$ Guild, Peers \& Tomkin 2014.

11 Guild, Peers \& Tomkin 2014.

12 Guild, Peers \& Tomkin 2014.

13 C-370/90, Surinder Singh, ECLI:EU:C:1992:296.
} 
The incentive to exercise a free movement right also becomes greater for families having trouble fulfilling onerous national requirements. But the CJEU has remained firm that EU law applies to this group. ${ }^{14}$

One of the most concerted efforts by some Member States to convince the CJEU to modify its constant jurisprudence took place in the context of a reference from the Netherlands in 2012 which was determined in 2014. ${ }^{15}$ The facts of the case reveal all the elements of the controversy which was arising in those Member States where national rules on family reunion and their EU counterpart had drifted apart. Two cases were joined together for consideration:

O: Mr O., a Nigerian national, married a Dutch national in 2006. Mr O lived in Spain from 2007 to April 2010 which was confirmed by the Spanish authorities. Ms O resided for two months with Mr O. in Spain between 2007 and April 2010 but she returned to the Netherlands because she could not find work in Spain. During that time, however, Ms O regularly spent time with Mr O. in the form of holidays in Spain. From 1 July 2010, Mr O. had been registered in the Netherlands according to the Personal Records Database as residing at the same address as $\mathrm{Ms} \mathrm{O}$. Mr O applied for a residence permit in the Netherlands but it was refused on the basis that it was unfounded (a national law requirement).

This set of facts revealed the concern of some Member States that the relationship between their citizen and a third country national is insufficiently stable to justify family reunion even though the couple are married. Should EU law be applicable, the ground for refusal would fall away.

The second set of facts are those of B: Mr B., a Moroccan national lived for several years in the Netherlands with his partner ('sponsor B') who has Dutch nationality. The Dutch authorities declared Mr B. to be undesirable as a result of a prison sentence of two months he received for using a false passport. Mr B. then moved to Belgium and lived in an apartment rented by sponsor B. Sponsor B stated that, during that period, she resided there every weekend. But the Belgian authorities rejected B's residence permit application and he moved to Morocco. In July 2007, Mr B. and sponsor B were married. Mr B. applied to have his declaration of undesirability lifted and a visa issued for family reunion. The story became somewhat more complicated but the end result was that the Dutch authorities refused $\mathrm{Mr} \mathrm{B}$ residence as the spouse of an EU returning Dutch national.

14 C-127/08, Metock and Others, [2008] ECR I-6241.

15 C-456/12, $O \& B$, ECLI:EU:C:2014:135. 
These facts reveal another set of worries by some Member States that EU law allows their citizens who have exercised a free movement right to bring home family members who have criminal convictions which would justify their exclusion from the territory under national law but not under EU law.

Seven Member States intervened mainly to support the Netherlands in the case: Belgium, the Czech Republic, Denmark, Germany, Estonia, Poland and the UK. One of the questions which would be revealed in the research was the extent to which the act of intervening in the case was related, or not, to the existing legal position of the seven intervenors. It might be expected that states intervene in court cases to protect their existing legislation or practices. In fact this did not turn out to the case for most of them.

In any event, the CJEU was unsympathetic to the concerns of the Dutch authorities. It held that where a Union citizen has created or strengthened family life with a third-country national during genuine residence in a host Member State under the Directive he or she is entitled to the same family reunion rules (by analogy) when returning to his or her Member State of origin. The conditions for entry and residence there of the third country national family member should not be more strict than those which apply in a host Member State.

Key for the CJEU was whether the EU citizens were actually exercising a free movement right more substantial that as tourists (Article 6 Directive 2004/38). In other words, were these EU citizens actually working, self-employed, studying or self-sufficient in which case they would be exercising a substantive right; or were they tourists subject to no conditions on entry but limited to three months residence and thus not exercising a substantive free movement right. The CJEU drew a dividing line between short stays as tourists and a genuine exercise of a free movement right which was capable of carrying a right to family reunion on return. This is the difference between Articles 6 (three months without conditions) and 7 (conditions on residence) of Directive 2004/38. The CJEU's rather generous approach to family reunion also fits with a practical issue of responsibility among Member States. If the conditions of family members to follow their EU principals home are more exclusionary than those which applies to their residence in the host state the consequence will be stranded family members. The third country national family members risk becoming a headache for the host Member State which may or may not want them, because these people have been unable to join their EU citizen principal in his or her home Member State.

Clearly, family reunion is a sensitive issue particularly when it engages citizens of the home State who have exercised their free movement rights and return with third country national family members. For the state authorities of the home state this may cause discrimination among their own citizens if 
they apply harsher family reunion rules to their citizens who do not move than EU law requires them to apply to their nationals who have moved. In order to understand what happens in practice, in the context of a research project under the Jean Monnet programme directed by the Radboud University's Centre for Migration Law, I canvassed legal experts in every Member State for information about their state's law and practice in respect of two questions (see below). The time period of the project was 2014 (the date of the judgment) and 2016, two years later a time period within which most Member States will have identified any problems with their national law and practice and in compliance with their duty of good faith to the EU should have or being in the process of remedying any shortcoming. The two questions I asked of the national experts were:

1. What are the effects in your national law of the CJEU judgment in the case of $O \& B$ where an EU national having exercised a free movement right seeks to return with third country national family members to the Member State of origin?

With this question, I sought to discover whether and which Member States had to change their national laws on family reunion to take account of the CJEU judgment. If they did have to change national law, I sought to understand how it came about.

2. What are the differences of national law in your Member State on family reunion for nationals of your state and EU law on family reunion for EU nationals exercising free movement rights?

With this question, I sought to discover whether over time there was increasing diverge of convergence of national law and EU law regarding family reunion. There have been a number of studies since the early 2ooos on national family reunion law and its EU counterpart. It was time to examine the question again.

On the basis of information provided by the national experts a very interesting picture emerges which indicates that few Member States had, in practice, substantial concerns about their own nationals coming back from exercising free movement rights accompanied by third country national family members. This was evidenced by national laws and rules which either provided for a harmonization of EU and national family reunion rules for their citizens or the assimilation of their own nationals returning to the rules applicable to EU citizens coming to exercise free movement rights in the country. In respect of national law and EU law on family reunion, I discovered that there is increasing convergence of national law towards EU law with a small number of exceptions. The results are set out here. 


\subsection{EU Member States and Their Citizens Returning with Third Country National Family Members}

How de Member States treat their own citizens who acquire third country national family members while exercising a free movement right in another Member State and then seek to return home with the whole family? By the time all the national experts had submitted their reports (2017), only one Member State (the UK) was still failing correctly to apply the judgment. Other Member States, with the exception of the Netherlands had not even had to change their guidance as it was already compliant. This was surprising and necessitated an examination of the differences between the treatment of EU citizens who have a right to family reunion under Directive 2004/38 and nationals of each Member State who are subject to national law only in this area which will be dealt with in the next section.

In this section, I set out the results of the investigation on the basis of the reports provided by the experts in the Member States about the impact of the $O \& B$ judgment in their country. The first group of states are those states where no change was needed to national law following the $O \& B$ judgment with an explanation where relevant as to why this was the case.

The first group of states reviewed here had in place legislation compliant with the CJEU's finding in $O \& B$. Even where the state was an intervener in the case, in fact its legislation and practice was already fully in accordance with the judgment which the CJEU would hand down. In Austria no change in legislation was needed as the Supreme Administrative Court ${ }^{16}$ had already held that Austrians returning to Austria from residence in another Member State and bringing with them third country national family members were entitled to do so long as their residence there had been sustainable. Even short periods of employment in another Member State were sufficient. In the Czech Republic there was apparently no reverse discrimination between the treatment of EU and Czech nationals. It was a little surprising then that this country participated in the $O \& B$ proceedings. Germany was not affected by the judgment either as its Federal Administrative Court ${ }^{17}$ had already decided in 2010 that residence which constitutes more than mere visits do entitled German nationals returning to Germany to bring their third country national family members with them. Thus no change to the law was needed. Again, the participation of Germany as an intervener in $O \& B$ seems to have been perhaps unnecessary unless this was to protect the existing position of German law at the time.

\footnotetext{
16 VwGH 23.2.2012, 2010/11/2011.

17 Bundesverwaltungsgericht 16 November 2010, 1 C 17.09 and 11 January 2011, 1 C 23.09.
} 
In Estonia there was no impact at all of the judgment (again raising the question why did this state bother participating in the proceedings?). Spain had already introduced equality between EU and Spanish nationals seeking family reunion in 2010. The purpose of this change in legislation was to lift the rights of Spanish nationals to the same level as those of EU citizens. Thus the judgment did not have any effect there. Finland also appeared to not have had any difficulty with the judgment. Its legislation already provided for family reunion for Finnish nationals where the relationship was established in the host state and there has been genuine residence there. No time limit was placed on the duration of that residence. In Greece there was no difference between the right of family reunion of Greek citizens and EU citizens thus the case had no impact. The same was true of Croatia. In Hungary although there was no legislation covering the issue in practice the administration applies the same rules to Hungarians coming home and EU citizens arriving. The administration did have issues about whether the relevant Hungarian nationals have actually moved back to Hungary or whether they were still living in another Member State (usually Romania) but setting up their family in Hungary. But this issue was clearly dealt with by the CJEU's judgment and did not necessitate a change of approach by the Hungarian authorities. Similarly, the judgment had no impact in Ireland where national policy has remained unchanged since 2013. In Luxembourg there was no need to take any action to implement the judgment. As well, in Latvia and Malta no changes were required. Poland, notwithstanding having intervened in the case of $O \& B$ had no legislation which creates an obstacle for Polish national returning to the country after exercising free movement rights in another Member State to bring with them third country national family members acquired there. However, Polish law did not recognize a right of permanent residence for these family members equivalent to that of family members who joined a Polish national resident in the state without moving. This difference of treatment was not in accordance with other provisions of Directive 2004/38 but is not part of the $O \& B$ effect.

In Portugal the case had no impact as the constitutional right of family life meant that the rights of Portuguese nationals returning from another Member State were fully protected to the same extent as EU nationals arriving for the first time. Again in Romania there were no practical implications of the case as Romanian national have wider family reunion rights even than EU citizens. Slovenia needed no change of law or practice after $O \& B$ as its law was in conformity. Slovakia did not change its law or practice either though it appears that Slovakian nationals returning after exercising free movement rights in another Member State where they acquired third country national 
Member States should seek visas for those family members before returning to Slovakia.

A second group of states, substantially smaller, were required to make minor amendments to their legislation to accommodate the CJEU's judgment. In Belgium a 2016 law clarified the difference between sedentary citizens and those who exercised a free movement right. A simple three months requirement was established for Belgians living in other Member States to be able to seek a visa for their third country national family members to return to Belgium with them. In Denmark a minor change of law was required to differentiate between economically inactive and economically active: as soon as Danish nationals become economically active in another Member State they are entitled to return with their third country national family members. All cases which had been rejected on this ground were re-opened after the $O \& B$ decision to ensure that Danish nationals who had incorrectly been refused family reunion would be able to benefit from the right rules. In Italy the judgment had very limited administrative consequences regarding the processing of applications by Italian nationals. Lithuania considered that the case had implications for same sex partnerships which was an issue of some political salience in that country. In Sweden while there did not appear to have been a substantial issue, nonetheless the legislature amended the law in 2014 to ensure that Swedish nationals returning there have the same rights as EU nationals on arrival.

A third group of states had, in 2017, on-going or substantial issues with implementing the judgment. Bulgaria comes within this group. The principle of $O \& B$ had still not been implemented by the end of that year. Instead a 2016 law and Supreme Court judgment ${ }^{18}$ of the same year provided that EU law on family reunification of third country nationals with third country nationalsDirective 2003/86 - applies to Bulgarian nationals returning home with third country national family members. This is not consistent with the $O \& B$ decision. France appeared to continue to have issues with third country national family members of French citizens when returning to France. The authorities continued to apply a visa requirement and require the passing of a test of the French language and values. The French authorities also applied expensive maintenance requirements and a cohabitation obligation contrary to the finding in $O \& B$. The Netherlands was the state against whose practices the case was brought. Following the judgment the authorities changed the guidelines regarding genuine residence in another state for its nationals returning after exercising free movement rights elsewhere in the EU. First, these authorities had

18 Case No 6o78/2015. 
required at least six months residence by their nationals in another Member State before accepting an application for a residence card for their third country national family members on return to the Netherlands. This was changed to three months after the judgment.

The United Kingdom fell within the group of states for whom the judgment came as a disagreeable surprise. The authorities, rather than bringing their law and practice into line with the judgment, changed their rules after the (British) Advocate General's Opinion (which was not upheld by the Court) which suggested that a much greater exercise of subsidiarity should be permitted. The result was that UK legislation was substantially inconsistent with the judgment including in 2017. National guidance on British citizens returning to the UK after exercising free movement rights in another Member State were required to prove that their residence in another Member State was not only genuine, but to do so had to show that the centre of their lives had moved to the other Member State. The length of residence of the third country national family members with the British citizen was considered to be highly relevant as well as whether the British citizen's residence in the host Member State was declared to all relevant authorities as his or her principal residence. Further the British citizen's integration into the host state was a relevant consideration as to whether the exercise of the free movement right was genuine. A long list of questions were posed to all families of British citizens returning to the UK after an exercise of a free movement right in another Member State which appeared to seek to tease out answers which would place in doubt the 'genuineness' of the move according to national law and thereby provide grounds for exclusion. Further, the right of residence of the third country national family members was strictly limited to the quality of the residence of the British sponsor - which had to be on the basis of work, self-employment, studies or self-sufficiency. As soon as the underlying ground for residence in EU law of the principal fell away (for instance unemployment or reliance of social assistance) the right of residence of the third country nationals also fell away and they were liable to expulsion unless they were able to bring themselves with the scope of national law (generally not possible because of the high income thresholds). If the divergence of national law from EU law and the resolute refusal to comply to a judgment of the CJEU is an indication of integration into the EU then the $\mathrm{UK}$ revealed itself in its response to this judgment alone. The logic of в REXIT and the insistence on national sovereignty over immigration control was already inscribed into the response of this Member State to the judgment.

Finally Cyprus stood alone as having no regulation in place on the issue at all. 


\subsection{National Law on Family Reunion and EU Law}

The second question I posed in this research related to the convergence or divergence of national family reunion law for citizens of the state with third country national family members with that of its EU counterpart. Article 2 Directive 2004/38 is generous as regards the conditions of family reunion of EU nationals who are exercising free movement rights. As set out in the introduction, the class is wide and augmented by a duty in Article 3 of the Directive to facilitate the admission of persons not coming within this group if they are 'other family members' as defined ${ }^{19}$ or in a durable partnership with the EU citizen (duly attested). Only students do not enjoy a right to be joined by family members in the ascending line. For workers and the self-employed there are no health insurance or minimum income thresholds applicable. ${ }^{20}$ These can only be applied in respect of economically inactive EU citizens.

In order to understand the reaction of Member States to the $O \& B$ judgment I sought to understand how different national law on family reunion for their own nationals who have not moved is from the right of family reunion for $\mathrm{EU}$ citizens moving to their state. This issue has been the subject of a number of studies over the past twenty years. ${ }^{21}$ Interestingly, over the years, there appears to be a convergence of EU family reunion rules for EU nationals exercising their free movement rights and nationals who do not move. This convergence, which diminishes the sense of unfairness between the treatment of EU nationals and own citizens, may be critical to the lack of difficulty which the vast majority of Member States have had with the CJEU's judgment in $O \& B$.

On the basis of information provided by the national experts, the first group of states, and by far the largest, were those where rights between own nationals and EU citizens regarding family reunion were converging. These included

19 These are family members who are dependent on the EU citizen and his or her spouse or formed part of the household in the state of origin or where serious health grounds strictly require the personal care of the family member by the Union citizen.

20 K. Groenendijk (2006) 'Family reunification as a right under community law', European Journal of Migration and Law 8(2), p. 215-230; A. Wiesbrock (2010) Legal migration to the European Union (Leiden: Brill/Nijhoff); C. Costello (2009) 'Metock: Free Movement and Normal Family Life in the Union', Common Market Law Rev. 46, p. 587-622.

21 A. Walter (2008) Reverse discrimination and family reunification (Nijmegen: Wolf Legal Publishers). K. Groenendijk (2006) 'Family reunification as a right under community law', European Journal of Migration and Law 8(2), p. 215-230; C. Costello, L. Halleskov Storgaard \& K. Groenendijk (2017) Realising the right to family reunification of refugees in Europe, Issue Paper by Council of Europe Commissioner for Human Rights (Brussels: Council of Europe); K. Groenendijk, E. Guild \& R. Barzilay (2001) The legal status of third-country nationals who are long-term residents in a Member State of the European Union (Nijmegen: University of Nijmegen). 
Austria (though the class of third country nationals for whom EU law only requires facilitation of family reunion is not equally applied). The Czech Republic also had no discrimination between EU and national citizens as regards family reunion. In this group also fell Estonia. Spain similarly had no difference between the treatment of EU and Spanish nationals as regards family reunion. In 2016, the Supreme Court ${ }^{22}$ rejected a law purporting to place a requirement of income or resources for the purposes of exercising a family reunion right for Spanish nationals. In 2015 the law was widened to include the EU group of family members entitled to facilitation for entry to join also Spanish nationals who had not exercised an EU free movement right. This was also the case in Croatia. Italy also came within this group of equality. Portugal also had no discrimination between the treatment of its nationals for the purposes of family reunion and EU nationals. This was protected by the constitutional right to family life. Romania was similar. In Sweden and Slovenia there were no substantial differences between family reunion for citizens and EU nationals.

The second group of states were those where there were minor difference between the EU right to family reunion with third country national family members and national law regarding own citizens. In Belgium sedentary citizens had a slightly higher set of requirements for family reunion with third country nationals than their EU counterparts. These included proving sufficient accommodation, health insurance even in the case of a Belgian worker principal, and a fairly low subsistence requirement. In Bulgaria there was a slightly more restrictive definition of family members than in the EU counterpart. In Germany there was equivalence as far as spouses and minor children go but no other family members where EU nationals were privileged. The Federal Constitutional Court ${ }^{23}$ had refused to consider the issue of reverse discrimination against German nationals vis-a-vis their EU counterparts and the compatibility of such discrimination with the constitution. In France, as mentioned above, the authorities continued to apply a visa requirement, the passing of a test of the French language and values. They also applied expensive maintenance requirements and a cohabitation obligation contrary to the finding in $O \& B$. Finland came within this group-national law was more restrictive for Finnish nationals than for EU citizens but the differences were not dramatic. Children were limited to those under 18 years and cohabitation for two years was required. There was no maintenance requirement but where there was no maintenance link nor a blood link between the putative parent and a child, the child could not establish a right to join the putative parent or

22 Supreme Court, 1 June 2010 Appeal 114/2007.

23 Bundesverwaltungsgericht 30.3.2010 1 C 8.09. 
to remain in Finland. Hungary came within this group as well as there were some administrative obstacles such as evidence in the form of proving cohabitation by means of a registered address. Also there were higher fees for Hungarian nationals than for EU citizens seeking family reunion. In Lithuania there were minor differences in rules on family reunion for own nationals and EU citizens but not so substantial as to place considerable obstacles in the way of nationals being joined by third country national family members. The same was true in Latvia where the group most discriminated against are same sex couples. Malta also followed this pattern but did not permit durable partners to work. Further, couples had to show stable and regular resources to support themselves. Poland also came within this group where the differences were minor. However a court judgment ${ }^{24}$ found that an EU national with a third country national spouse where the EU national naturalized as a Polish citizen was disadvantaged in that his spouse could not get a permanent residence permit as the national rules which are more advantageous for Polish nationals (three years residence in the state and marriage to a Polish national) were not fulfilled because the Polish national had only recently become one. In Slovakia there were only minor differences in the treatment of own nationals and EU citizens regarding family reunification with third country national family members. There was an interview requirement and also a visa obligation.

A third group of states were those where there were substantial difference between the treatment of own nationals (disadvantageously) in comparison with the more generous rules which apply in EU law. This difference was usually the reason for political, administrative and judicial reluctance to recognize the rights of EU nationals and in particular the assimilation of own nationals who had exercised a free movement right to the class of persons entitled to the wider EU rights. Denmark came within this group of states where the difference between a restrictive national family reunion law and EU rules come into conflict. For Danish nationals, family reunion was only possible where very strict rules on genuine residence were fulfilled and it was clear that this was necessary to strengthen family life. Only spouses over the age of 24 could join a Danish national in Denmark and children under 15 years of age. There was an obligatory declaration of cohabitation and a substantial financial guarantee was required from the sponsor. Public assistance was not permitted at all for the first three years and the aggregate ties to Denmark of the couple had to be greater than their ties to any other country in the world and proven. There was an accommodation and integration test to be past. The couple had to undertake to teach their children the Danish language. Further the primary purpose

24 1 July 2015 IV A/Wa 1284/15. 
of the marriage had not be for the foreign spouse to come to Denmark (a negative burden of proof). In Ireland there was no right to family reunion with third country national family members. Family reunion was a 'gift' of the state not an entitlement. Many factors therefore needed to be taken into account including economic ones which carried the most weight - in particular whether the family could support itself properly without recourse to public funds. Not only was there a higher income threshold but the documentary evidence required was substantially more onerous. The Netherlands also came within this group with very substantial difference between the treatment of their own nationals with no free movement background in comparison with EU nationals. Not only were there substantial income thresholds, health insurance requirements, language and integration test but also high fees for applications and special visa requirements. The $U K$ had substantial differences in its law on family reunion for British nationals and EU citizens. These included visa requirements, high fees, language requirements, very high income requirements, obligatory health insurance and accommodation requirements. All of the requirements were applied in an administratively complex and document heavy procedure with no time limits on the state's consideration of the application.

A fourth group was that where there is no clear definition-Cyprus where the rights in particular of Turkish Cypriots remain unclarified.

A number of aspects of this review of national law in the light of a judgment of the CJEU and the convergence of EU law and national law on family reunion are revealing. First, notwithstanding the number of Member States which intervened in the case before the CJEU, it appeared that most of the interveners actually had no specific legal interest in the case as their national law already provided for assimilation of the rights of their nationals to those of $\mathrm{EU}$ citizens moving to their country, Thus the differential between the treatment of own citizens and EU citizens was equal to zero and not controversial. It remains unclear why, then, these states did intervene in the case considering that there was no particular interest from the perspective of their own national law in a clarification of the EU obligation.

Secondly, only five EU states had substantially different national law on family reunion for their own citizens from those applicable to EU citizens coming to live there (and own citizens returning after exercising free movement rights). These are Denmark, France, Ireland, Netherlands and UK. These states had a real problem of reverse discrimination vis-a-vis their own nationals 
whose treatment as regards family reunion was substantially inferior to that of EU nationals. It is this differential which appeared to push their citizens to go to other Member States to exercise free movement rights with the idea in mind of exercising their family reunion rights under EU law and possibly moving back to their home Member States afterwards. All five of these states appear, from the political discourse, to consider that this exercise of EU rights simply for the purposes of better family reunion right was somehow an abuse of rights which they should be entitled to stop. This discourse was particularly abrasive in the UK. ${ }^{25}$

Thirdly, the number of Member States where the family reunion rights of their own nationals have been assimilated to that of EU citizens had become the majority. Since the study by Walter in 2008, there has been a substantial move towards greater harmonization. ${ }^{26}$ This has not been the result of legislation as EU law does not require Member States to change their laws as regards their own nationals but rather seems to be the result of a gradual move towards simplification and assimilation of EU rules, including beyond the actual scope of EU law.

25 E. Guild, BREXIT and its Consequences for UK and EU Citizenship or Monstrous Citizenship (Leiden, Brill, 2016).

26 A. Walter, Reverse discrimination and family reunification (Nijmegen, Wolf Legal Publishers, 2008). 